\title{
Let's Twist Again: A High-Frequency Event-Study Analysis of Operation Twist and Its Implications for QE2
}

\author{
Eric T. Swanson \\ Federal Reserve Bank of San Francisco
}

February 2011

Working Paper 2011-08

http://www.frbsf.org/publications/economics/papers/2011/wp11-08bk.pdf

The views in this paper are solely the responsibility of the authors and should not be interpreted as reflecting the views of the Federal Reserve Bank of San Francisco or the Board of Governors of the Federal Reserve System. 


\title{
Let's Twist Again: A High-Frequency Event-Study Analysis of Operation Twist and Its Implications for QE2
}

\author{
Eric T. Swanson \\ Federal Reserve Bank of San Francisco \\ eric.swanson@sf.frb.org \\ http://www.ericswanson.org
}

\begin{abstract}
This paper undertakes a modern event-study analysis of Operation Twist and compares its effects to those that should be expected for the recent quantitative policy announced by the Federal Reserve, dubbed "QE2". We first show that Operation Twist and QE2 are similar in magnitude. We identify six significant, discrete announcements in the course of Operation Twist that potentially could have had a major effect on financial markets, and show that four did have statistically significant effects. The cumulative effect of these six announcements on longer-term Treasury yields is highly statistically significant but moderate, amounting to about 15 basis points. This estimate is consistent both with Modigliani and Sutch's (1966) time series analysis and with the lower end of empirical estimates of Treasury supply effects in the literature.
\end{abstract}

JEL Classification: E43, E52, E58, E63, E65, N12

Version 1.0

February 19, 2011

I thank David Romer and Justin Wolfers for helpful comments and suggestions, and Titan Alon for valuable archival work and research assistance. The views expressed in this paper, and all errors and omissions, should be regarded as those solely of the author, and are not necessarily those of the individuals listed above, the management of the Federal Reserve Bank of San Francisco, or any other individual in the Federal Reserve System. 


\section{Introduction}

On December 16, 2008, the Federal Reserve System's Federal Open Market Committee (FOMC) lowered the target for the federal funds rate to essentially zero in response to the most severe U.S. financial crisis since the Great Depression. Since U.S. currency carries an interest rate of zero, it is virtually impossible for the FOMC to target a value for the federal funds rate that is appreciably below zero. Faced with this zero lower bound, the FOMC in 2008 and 2009 endeavored to find alternative ways to stimulate the weak U.S. economy, such as by purchasing large quantities of mortgage-backed securities and longer-term Treasuries in an effort to improve the functioning of those markets and reduce long-term interest rates. ${ }^{1}$

In late 2010, in response to continuing weakness in the economy and the zero lower bound, the FOMC embarked on a second round of quantitative policies, announcing its intention to purchase "a further $\$ 600$ billion of longer-term Treasury securities by the end of the second quarter of 2011." ${ }^{2}$ This program has subsequently become known as "QE2" by the financial community and financial press.

The QE2 program has been controversial, with detractors conjecturing that the risks or costs of the policy are large while the benefits are small. For example, an open letter to Federal Reserve Chairman Bernanke signed by several prominent economists and published in full-page ads in The Wall Street Journal and The New York Times asserted that the purchases "risk currency debasement and inflation" and could "distort financial markets" while "we do not think they will achieve the Fed's objective of promoting employment" and are "neither warranted nor helpful in addressing either U.S. or global economic problems" (e21 Team, 2010).

The present paper aims to estimate the potential benefits of QE2 by measuring the effect on long-term interest rates of Operation Twist, a very similar program undertaken by the Kennedy administration and the Federal Reserve in 1961. Although previous studies of Operation Twist using low-frequency, quarterly data have generally found no significant

\footnotetext{
${ }^{1}$ On November 25,2008 , the FOMC announced it would purchase $\$ 500$ billion of mortgage-backed securities and $\$ 100$ billion of debt directly issued by the housing-related government-sponsored enterprises (GSEs). On March 18, 2009, the FOMC announced that it would purchase an additional $\$ 750$ billion of mortgage-backed securities, an additional $\$ 100$ billion of GSE debt, and $\$ 300$ billion of longer-term Treasury securities. FOMC statements and minutes are available from the Federal Reserve Board's public web site.

${ }^{2}$ FOMC statement, Nov. 3, 2010, available from the Federal Reserve Board's public web site.
} 
effect of the program on long-term interest rates - see, e.g., the exhaustive time series analysis by Modigliani and Sutch $(1966,1967)$ - the present paper undertakes a more modern high-frequency event-study approach. The event-study methodology restricts attention to major announcements in the course of Operation Twist that can be pinpointed to a single day or two. By focusing on changes in Treasury yields in a narrow window surrounding each announcement, an event study holds other factors affecting the macroeconomic outlook constant, and thereby isolates the effects of the announcement itself on the yield curve. Lower-frequency time series analyses must attempt to control for other factors affecting the yield curve directly, which is fraught with difficulties such as unobserved variables (financial market expectations of future interest rates and inflation), large residual errors, and endogeneity, as discussed in Section 3, below.

In contrast to Modigliani and Sutch, we find that Operation Twist had a highly statistically significant effect on longer-term Treasury yields. However, consistent with Modigliani and Sutch's (1966) finding that any effects of Operation Twist "are most unlikely to exceed some ten to twenty base points" (p. 196), we estimate that the size of these effects is moderate, with a cumulative effect on long-term Treasury yields of about 15 basis points. This is also consistent with the lower end of Treasury supply effects estimated elsewhere in the literature, discussed at length in Section 5, below.

Operation Twist also has several advantages over more recent episodes as a laboratory for estimating the likely effects of QE2. For example, estimates of the effects of the Fed's initial round of quantitative policies in 2008 and 2009 - what one might call "QE1" — such as the studies by Gagnon, Raskin, Remasche, and Sack (2010) and D'Amico and King (2010), are subject to the concern that the 2008-9 financial crisis was a time of severe financial market disruption and low liquidity (see, e.g., Gürkaynak and Wright, 2011). The exceptionally low level of liquidity and poor functioning of financial markets during this period may have led Federal Reserve purchases to have an uncharacteristically large effect on markets. Thus, it is not clear that the effects of Fed purchases during QE1 are representative of the effects we might expect in more normal times, such as the present environment in which QE2 is being conducted.

In addition, foreign government institutions have become increasingly large participants in the U.S. Treasury market over time, with foreign official institutions now collectively 
holding almost $\$ 3$ trillion of U.S. Treasury securities - about one-third of the market - of which more than $\$ 2.3$ trillion is held in longer-term Treasury notes and bonds. ${ }^{3}$ As discussed by Warnock and Warnock (2009), foreign official purchases of U.S. Treasuries often vary by a hundred billion dollars or more over the course of a few months, due to largely exogenous factors such as domestic economic developments and exchange rate interventions. Foreign official purchases necessarily complicate any analysis of Treasury supply effects over the past 25 years, and Warnock and Warnock estimate that these purchases themselves have had a large effect on Treasury yields. An advantage of the Operation Twist period is that the extent of foreign government involvement in the U.S. Treasury market was so small that it can safely be ignored.

The remainder of the paper proceeds as follows. Section 2 provides the historical context for Operation Twist and shows the remarkable similarities between that program and QE2. Section 3 describes our event-study methodology and the data. Results of our analysis are presented in Section 4. Section 5 compares these results to other estimates of Treasury supply effects in the literature. Section 6 concludes.

\section{Operation Twist}

John F. Kennedy was elected President of the United States in November 1960 and inaugurated on January 20, 1961. The U.S. economy had been in recession since April of 1960 and the recession was ongoing (it would ultimately end in February 1961, although the level of economic activity would remain low for several months into the recovery). The incoming administration wanted to stimulate the economy with easier monetary as well as fiscal policy, but European interest rates were higher than in the U.S., leading to substantial flows of dollars and gold to Europe under the Bretton Woods fixed exchange rate system. The Federal Reserve was very reluctant to lower short-term interest rates for fear of worsening the U.S. balance of payments and the outflows of gold to Europe.

The Kennedy administration's proposed solution to this dilemmma was to try to lower longer-term interest rates while keeping shorter-term interest rates unchanged. The idea was that business investment and housing demand were primarily determined by longer-term

\footnotetext{
${ }^{3}$ Data are for October 2010 from the U.S. Treasury's "Major Foreign Holders of U.S. Treasury Securities" report, available at http://www.treasury.gov/resource-center/data-chart-center/tic.
} 
interest rates, while the balance of payments and gold flows were determined by cross-country arbitrageurs who act on the basis of short-term interest rate differentials. If longer-term Treasury yields could be lowered without affecting short-term Treasury yields, the reasoning went, then investment could be stimulated without worsening the balance of payments and gold outflow. ${ }^{4}$

Thus, on February 2, 1961, Kennedy announced to Congress a policy in which the Treasury and Federal Reserve would cooperate to change the relative supplies of long-term and short-term Treasury securities in the open market. The Federal Reserve would maintain the current level of the federal funds rate, but would buy longer-term Treasury securities to try to nudge longer-term interest rates lower. The Treasury would reduce its issuance of longer-term notes and bonds and instead issue primarily short-term securities. ${ }^{5}$ At the time, this policy was referred to by Fed staff as "Operation Nudge," but in retrospect it has become known as "Operation Twist," in homage to the dance craze that swept the nation at about the same time. ${ }^{6}$

According to statistics from the Federal Reserve Bank of New York, the Fed ultimately purchased about $\$ 8.8$ billion of longer-term bonds as part of Operation Twist. ${ }^{7}$ Recent authors have sometimes dismissed this program as being very small (e.g., Gagnon et al., 2010), but in fact the size of Operation Twist is quite comparable to QE2. This is demonstrated in Table 1, which reports the nominal size of both programs along with nominal GDP and various measures of U.S. Government debt outstanding. Marketable U.S. Treasury debt includes nominal and inflation-indexed Treasury securities in the hands of the public and excludes nonmarketable securities issued to the Social Security Administration, state and local governments, and to households in the form of savings bonds. ${ }^{8}$ U.S. Agencies include the Federal Home Loan Banks, Federal National Mortgage Association (Fannie Mae),

\footnotetext{
${ }^{4}$ See The Wall Street Journal, Feb. 3, 1961, p. 2, and Feb. 9, 1961.

${ }^{5}$ For additional details and discussion, see The Wall Street Journal, Feb. 3, 1961, p. 2, and Feb. 9 , 1961.

6 Meulendyke (1998), p. 39.

${ }^{7}$ Meulendyke (1998). In particular, the Fed increased its holdings of longer-term Treasury securities by $\$ 8.8$ billion and reduced its holdings of short-term Treasury bills by $\$ 7.4$ billion. For several years prior to Operation Twist, the Federal Reserve had subscribed to a "bills-only" policy and held no longer-term Treasury securities (The Wall Street Journal, Feb. 21, 1961, p. 3.)

${ }^{8}$ Data are from the U.S. Treasury's Office of Public Debt Management for January 1961 and October 2010. Data on nominal GDP are from the Bureau of Economic Analysis for 1961Q1 and 2010 Q3.
} 


\section{Table 1: Size of Operation Twist in Comparison to QE2}

\begin{tabular}{lcc} 
& Operation Twist & QE2 \\
\hline Size of Federal Reserve program (\$B nominal) & 8.8 & 600 \\
U.S. GDP (\$B nominal) & 528 & 14,730 \\
U.S. Treasury marketable debt (\$B nominal) & 189.3 & 8,543 \\
U.S. Agency debt (\$B nominal) & 7.4 & 6,449 \\
U.S. Agency-guaranteed debt (\$B nominal) & 0.2 & 1,121 \\
Size of Federal Reserve program: & & \\
$\quad$ as \% of GDP & $1.7 \%$ & $4.1 \%$ \\
as \% of U.S. Treasury debt & $4.7 \%$ & $3.7 \%$ \\
as \% of U.S. Treasury-guaranteed debt & $4.5 \%$ & No \\
Additional supporting program by U.S. Treasury? & Yes & \\
\hline
\end{tabular}

Notes: Size of Operation Twist is from Meulendyke (1998) and debt statistics are from the U.S. Treasury and Federal Reserve Flow of Funds. U.S. Treasury marketable debt excludes debt held by the Social Security Administration. U.S. Agencies include Fannie Mae and Freddie Mac, whose debt was implicitly (and later explicitly) guaranteed by the U.S. Treasury. U.S. Agency-guaranteed debt consists primarily of mortgage-backed securities. During Operation Twist (but not QE2), the Treasury deliberately issued securities with shorter maturities than usual, but the size of this shift is difficult to quantify, other than that it amounted to several billion dollars. See text for details.

Federal Home Loan Bank Corporation (Freddie Mac), and a few smaller entities. ${ }^{9}$ U.S. Agency-guaranteed debt consists almost entirely of mortgage-backed securities.

Although the debt of the U.S. agencies is not officially backed by the "full faith and credit" of the U.S. government, these agencies had close historical ties to the government and their securities were widely viewed as having an implicit government guarantee (a view that was subsequently confirmed in September 2008, when the U.S. government placed Fannie and Freddie into receivership and explicitly guaranteed their debt obligations). ${ }^{10}$ As a result, Agency-issued and Agency-backed securities have been, ex ante and ex post, close substitutes for U.S. Treasury securities.

As can be seen in Table 1, the Federal Reserve's purchases of long-term Treasury securities during Operation Twist were roughly comparable to QE2 along several dimensions.

\footnotetext{
${ }^{9}$ The data in the table are from the Federal Reserve's Flow of Funds accounts, Tables L.124-125, for 1961Q1 and 2010Q3. Note that, in the first quarter of 2010, about $\$ 4$ trillion of mortgage-backed securities guaranteed by Fannie Mae and Freddie Mac were shifted directly onto the balance sheets of those agencies in the Flow of Funds. This reclassification does not affect the sum of U.S. Agency debt and U.S. Agencyguaranteed debt, but it has a large effect on the breakdown between these two categories.

10 The U.S. Treasury initially announced a capital injection into Fannie and Freddie of up to $\$ 100$ billion each. This guarantee was later doubled to $\$ 200$ billion each and then made unlimited in December 2009 .
} 
First, Operation Twist was about half as large as QE2 relative to GDP — smaller, but similar enough in magnitude to be informative. Second, if changes in the supply of long-term Treasuries have any effect on long-term Treasury yields, then the initial quantity of longterm Treasury securities in the market should be a much more relevant initial condition than GDP. This observation suggests that the total Treasury market would be a better benchmark for the size of each program, and by this metric, Operation Twist was closer in size to QE2. Third, to the extent that U.S. Agency and Agency-guaranteed debt are close substitutes for Treasury securities, then the relevant market arguably includes all three of these Treasuryguaranteed classes of securities. ${ }^{11}$ Relative to this market, Operation Twist was an even bigger program than QE2.

Finally, a key feature of Operation Twist, emphasized by the Kennedy administration from the outset, was the joint participation by both the Federal Reserve and Treasury. While the Fed was purchasing $\$ 8.8$ billion of longer-term Treasury securities in the open market, the Treasury was actively supporting this policy by concentrating its issuance of new Treasury securities at shorter rather than longer maturities, by an amount that totaled at least several billion dollars. ${ }^{12}$ By contrast, the QE2 program has had no discernible support from the Treasury and, in fact, the average duration of U.S. Treasury securities issued and outstanding both increased in the second half of 2010, directly counter to the Fed's goals (Hamilton and $\mathrm{Wu}, 2011$ ). If one takes into account the Treasury as well as Federal Reserve contribution to these programs, then Operation Twist appears to have been substantially larger than QE2.

Operation Twist and QE2 are also very similar qualitatively as well as quantitatively. In both episodes, the Federal Reserve was unable or unwilling to lower its target for the federal funds rate - in the case of QE2, because of the zero lower bound on short-term rates, while in the case of Operation Twist, because of the large gold outflows. Thus, the goal of both programs was to lower longer-term Treasury yields without lowering the federal funds rate.

\footnotetext{
${ }^{11}$ One could extend this argument to all AAA-rated debt securities, or even to all debt securities, but at each successive step the similarity of state-contingent payoffs to U.S. Treasury securities diminishes. In Table 1, we end the scope of the market at U.S. Agency and Agency-backed debt, since the substitutability and set of state-contingent payoffs of those securities is the closest to U.S. Treasuries.

${ }^{12}$ For example, the Feb. 2 Treasury announcement in Table 2 had a total issuance size of $\$ 6.9$ billion. However, Treasury's Mar. 15 announcement revealed that its commitment to Operation Twist was only partial, rather than full - see the discussion of that announcement in Section 3.2. Thus, it is difficult to come up with a more precise estimate of the size of Treasury's participation in the program, other than that it amounted to several billion dollars.
} 
The methods used to implement each program are also very similar: for Operation Twist, the Fed and Treasury essentially sold short-term Treasury bills and purchased longer-term Treasury notes and bonds. To implement QE2, the Federal Reserve is financing purchases of longer-term Treasuries by issuing bank reserves. Bank reserves are short-term liabilities of the Federal Reserve rather than the Treasury, but aside from this technical distinction, the implementation of the two policies, Operation Twist and QE2, is essentially identical.

In summary, then, Operation Twist was remarkably similar to QE2 in many important respects. One can even make a strong case that Operation Twist was larger than QE2 and thus its effects could be an upper bound for those of the more recent program.

\section{Methods and Data}

Given the similarities between Operation Twist and QE2, it seems reasonable to use Operation Twist to estimate the likely effects of QE2. However, previous studies of Operation Twist using lower-frequency regression methods, such as the the exhaustive analysis by Modigliani and Sutch $(1966,1967)$ using quarterly data, have generally found no statistically significant effects of the program. Here we reexamine the episode using a high-frequency event-study approach.

\subsection{High-Frequency Event Study Analysis}

A high-frequency event-study analysis uses changes in financial markets in a narrow window of time around major, discrete announcements to measure the effects of those announcements. Under the hypothesis of rational expectations in financial markets, asset prices should completely incorporate all information from a public announcement shortly after the announcement is made. In particular, studying the one- or two-day change in Treasury yields around a major macroeconomic announcement should be sufficient to provide an unbiased estimate of the complete effect of that announcement on the yield curve. Jones, Lamont, and Lumsdaine (1998) and Fleming and Remolona (1999) provide evidence supporting this hypothesis, with no evidence of either "momentum" or "backtracking" in yields in the days following such announcements. ${ }^{13}$ Intuitively, it also seems reasonable that financial markets

\footnotetext{
13 Although the finance literature has found evidence of over- or underreaction in some cases for smallcapitalization stocks, such effects have not been documented for larger, more liquid markets such as the S\&P 500 or the Treasury market. Indeed, Jones et al. (1998) and Fleming and Remolona (1999) provide evidence to the contrary for the Treasury market.
} 
would not leave large riskless profitable trading opportunities unexploited for more than a few hours, let alone one or two days.

There are several reasons to think that a high-frequency event-study analysis would be more powerful than lower-frequency time series methods for detecting the effects of Operation Twist. First, longer-term Treasury yields are very sensitive to market expectations about macroeconomic variables such as inflation and the expected path of the federal funds rate. Unfortunately, these expectational variables can change quite dramatically from one quarter to the next and are unobserved by the econometrician, making them very difficult to incorporate into a regression framework. ${ }^{14}$ A high-frequency event-study analysis holds the macroeconomic outlook essentially constant by considering changes in yields across a one- or two-day window surrounding the announcement, across which the macroeconomic outlook changes very little except for the possible effects of the announcement itself. ${ }^{15}$

Second, the effects of Operation Twist may have been relatively small, on the order of ten or twenty basis points, which is no bigger than the quarterly standard deviation of long-term Treasury yields. Modigliani and Sutch's (1966) quarterly regression model has a residual standard error of 9.3 basis points, which they characterize as "remarkably low" (p. 190) relative to the rest of the literature. Given the size of this standard error, it might be impossible to find statistically significant effects of Operation Twist even if the regression model is correctly specified and the size of those effects is correctly estimated. By contrast, daily changes in long-term interest rates are about two basis points, so it is relatively easy to determine whether a major announcement regarding Operation Twist had a statistically significant impact on long-term bond yields that day.

Finally, there is an endogeneity problem with monthly or quarterly interest rate data that can make obtaining structural or causal estimates of the effects of Operation Twist difficult, if not impossible. This is similar to the problem of identifying the effects of a monetary policy shock in a vector autoregression, which requires an identifying assumption to disentangle the effects of changes in interest rates on the macroeconomy from the effects

\footnotetext{
${ }^{14}$ One can try to control for expectations to some extent by using survey data; however, such survey data do not exist for the Operation Twist period.

15 Of course, this requires that no other major macroeconomic data surprises or announcements occur on the same day as the announcement in which we are interested. For each of our identified announcements below, we verify this assumption by reading the bond market commentary for that day.
} 
of changes in the macroeconomy on interest rates (e.g., Christiano, Eichenbaum, and Evans, 1999). Modigliani and Sutch $(1966,1967)$ estimate a reduced-form time series model for long-term interest rates and then investigate to what extent changes in the relative supply of longer-term Treasury securities can explain the residuals of that reduced-form model. But if the Federal Reserve tended to step up its purchases of longer-term Treasuries whenever long-term interest rates started to rise - a plausible hypothesis - then Modigliani and Sutch's reduced-form approach will be biased toward finding no effect of Fed purchases on longerterm yields, or even the perverse effect that Fed purchases caused longer-term yields to increase. A high-frequency event-study analysis avoids this endogeneity problem as long as each major announcement being considered was not a response to changes in long-term interest rates on that same day. ${ }^{16}$

For all of these reasons, then, an event-study approach offers many advantages over - or at least a worthwhile alternative to-low-frequency time series methods for estimating the effects of Operation Twist.

\subsection{Six Major Announcements}

To perform an event-study analysis, we must first identify major announcements in the course of Operation Twist that carried significant news about the program and whose release can be pinpointed to a single day or two. We first performed a search in the ProQuest Historical Newspapers database for all articles in The Wall Street Journal in 1961 and early 1962 that mentioned the Federal Reserve or Treasury. ${ }^{17}$ This produced several hundred results. We quickly read through these articles, and the WSJ's weekly bond market recaps, to identify episodes that were related to Operation Twist - that is, the objective of lowering longerterm interest rates. This narrowed the number of relevant articles down to a few dozen. Of these, we identified six that, rather than rehashing the goals and methods of the program, represented major new announcements in the development of Operation Twist. These six announcements are summarized in Table 2 .

\footnotetext{
${ }^{16}$ For more discussion of this point and an application of high-frequency methods to identify the effects of monetary policy shocks in a VAR, see Faust, Swanson, and Wright (2004).

${ }^{17}$ Unfortunately, a search for the phrase "Operation Twist" over this period yields no results because the program did not come to be known by that name until a few years later. Also note that the widely-used LexisNexis database does not cover news articles before 1977.
} 


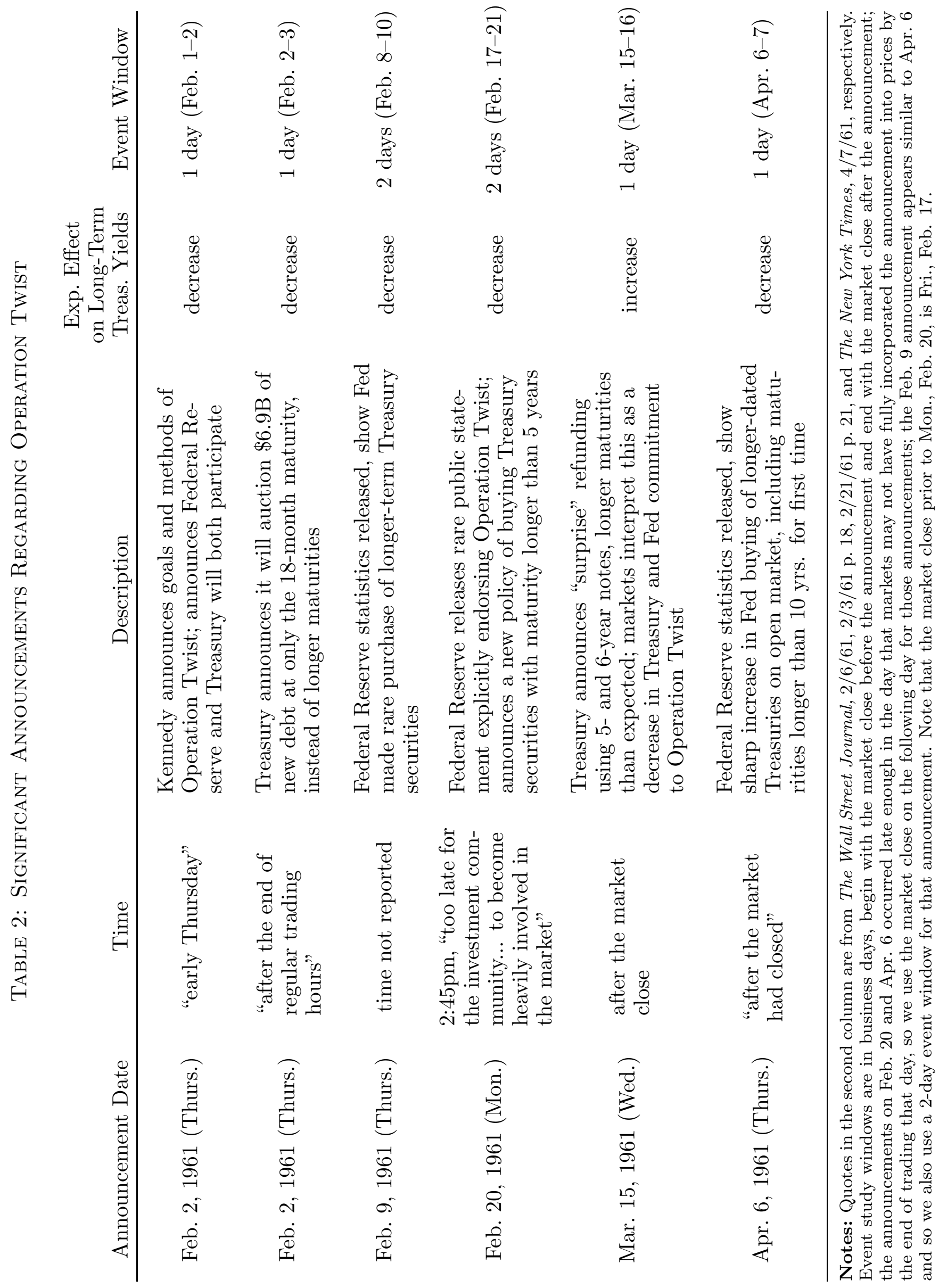


The first of these announcements is President Kennedy's introduction of the program on February 2, 1961. According to The Wall Street Journal, the announcement took place early in the day as part of an "economic message" from the President to Congress, in which the President outlined the rationale, goals, and methods of Operation Twist and announced that the Federal Reserve would support the Treasury in its implementation. ${ }^{18}$ According to bond market commentary in The Wall Street Journal, the announcement had a significant impact on bond markets and was the main driver of bond yields that day. Because the announcement occurred early in the day, leaving plenty of time for markets to respond, we use a one-day event window, from the market close on Feb. 1 to the market close on Feb. 2, to measure the effects of the announcement on Treasury yields.

A few hours after the President's message, "after the end of regular trading hours," the Treasury declared that its upcoming refunding of $\$ 6.9$ billion of Treasury debt would be concentrated entirely at the 18 -month maturity, instead of longer maturities. ${ }^{19}$ The announcement was obviously intended to bolster the President's introduction of Operation Twist earlier in the day, but the size and complete concentration of the refunding at shorter maturities may have been a surprise to financial markets and could have created additional follow-on effects on bond yields the next day. Because the announcement occurred after the close of trading on Feb. 2, we use a one-day event window from the market close on Feb. 2 to the market close on Feb. 3 to measure the effect of the refunding announcement.

Several days later, on February 9, the Federal Reserve released its weekly breakdown of Treasury security holdings by maturity for the week ended Wednesday, February 8. The report showed the Fed had made a rare addition to its holdings of longer-term Treasury securities during the week, which was noteworthy because for the previous ten years the Fed had followed a "bills-only" policy of purchasing only Treasury bills with 12 months or less to

\footnotetext{
${ }^{18}$ This economic message should not be confused with The Economic Report of the President, which was released by President Eisenhower on January 18, 1961, two days before Kennedy's inauguration. Kennedy's economic message announced and outlined Operation Twist, and the details were subsequently filled in by Administration officials in conversations with reporters. Although the economic message contained other economic proposals, such as a temporary extension of unemployment benefits, many of these other proposals had been anticipated by Kennedy's Jan. 30 State of the Union Address, executive orders, and speeches. Contemporary accounts in The Wall Street Journal focus almost entirely on Operation Twist, so there appears to have been little else in the message of comparable interest to financial markets. See The Wall Street Journal, Feb. 3, 1961, p. 2., p. 18, and Feb. 6, 1961. For the text of Kennedy's economic message, State of the Union Address, and executive orders, see Woolley and Peters (2010).

19 Articles describing this announcement are the same as for the previous announcement. The quote is from The Wall Street Journal, Feb. 3, 1961, p. 18.
} 
maturity except in the event of a substantial disruption in longer-term Treasury markets. ${ }^{20}$ Although the Fed's purchase was not particularly large and the maturity was not very long (just over 1 year), it was a clear departure from its bills-only policy and the first signal from the Fed (rather than the Administration) that it was at least tentatively supporting Operation Twist. ${ }^{21}$ The timing of the Fed's statistical release on Feb. 9 is not reported by either The Wall Street Journal or The New York Times, but other such releases were typically made late in the day (see, e.g., the April 6 announcement, below). Since the timing of the release on Feb. 9 is unclear, we use a two-day event window from the market close on Feb. 8 to the market close on Feb. 10 to measure the impact of this announcement. ${ }^{22}$

The Federal Reserve dramatically increased its commitment to Operation Twist a few days later, on February 20, 1961. That afternoon, the Federal Open Market Committee released what was then an extremely rare public statement, describing a change in its government bond-buying policy. The announcement read, in part:

During recent years, transactions for the system account, except in correction of disorderly markets, have been made in short-term U.S. Government securities. Authority for transactions in securities of longer maturity has been granted by the open market committee of the Federal Reserve System in the light of conditions that have developed in the domestic economy and in the U.S. balance of payments with other countries.

(The Wall Street Journal, Feb. 21, 1961, p. 3)

The release also explicitly extended the scope of Federal Reserve purchases of Treasury securities to maturities greater than five years. ${ }^{23}$ The announcement was striking, both for the manner of its release and because of its clear endorsement of the goals and methods of Operation Twist. Any previous doubts about the degree to which the Fed was committed to the Kennedy Administration program were immediately dispelled with this announcement.

\footnotetext{
${ }^{20}$ For more discussion of the Fed's bills-only policy, see The Wall Street Journal, Feb. 21, 1961 , p. 3.

${ }^{21}$ For example, The Wall Street Journal, Feb. 10, 1961, reported that "The Kennedy Administration has been seeking the cooperation of the Federal Reserve Board to bring down long-term interest rates," but that "The Federal Reserve has not said whether it plans any change in its open-market operations to nudge long-term rates downward."

22 Given the timing of the Apr. 6 announcement, it is very likely that the Feb. 9 announcement also occurred after the market close. We use a two-day window here to be on the conservative side, but using a one-day window would make essentially no difference in the results (see Table 3, below).

23 The Wall Street Journal, Feb. 21, 1961, p. 3 and p. 21. A few days later, on Feb. 23, the Federal Reserve's weekly balance sheet report confirmed that it had in fact purchased a significant quantity of such securities. However, these purchases were not a surprise given the Feb. 20 statement (The Wall Street Journal, Feb. 24, 1961), so we do not include Feb. 23 among our announcements in Table 2.
} 
The Fed's statement was released at 2:45pm, reportedly "too late for the investment community at large to become heavily involved in the market." 24 Thus, we use a two-day event window for this announcement, from the market close on Friday, Feb. 17 to the market close on Tuesday, Feb. 21.

The four announcements above each signaled an increasing degree of commitment by the Treasury or the Federal Reserve to Operation Twist. In contrast, on March 15, 1961, a Treasury announcement was perceived by financial markets as a decreased degree of commitment to the program. After the markets closed that afternoon, the Treasury announced an advance debt refunding operation, in which an offer is made to exchange soonto-mature Treasury securities for newly-issued, longer-maturity Treasuries. ${ }^{25}$ The refunding itself was not so much a surprise as was the timing of the announcement (during Operation Twist) and the surprising length of the debt maturities being offered in exchange (five and six years). As reported by The New York Times, "Market circles had expected that the advance refunding device... would be used by the Treasury again, but not so soon, and especially not while the Federal Reserve System was engaged in a market operation... aimed at reducing long-term interest rates." 26 According to the The Wall Street Journal, "Some interpreted the advance refunding as indicating a change of thinking by the Treasury and the Federal Reserve System," in particular that it " "may mean the monetary authorities, including the Federal Reserve, are satisfied with prices and rates prevailing in the bond market [and] may believe that business in general is on the road to recovery.'" 27 The expected effect of this announcement on long-term interest rates is thus opposite to the effects of the first four

24 The Wall Street Journal, Feb. 21, 1961, p. 21. In the early 1960s, government securities trading desks typically closed at $3: 30 \mathrm{pm}$. Moreover, daily quotation sheets distributed to clients and newspapers typically were based on 2:30pm price quotations, so it is unclear whether any effects of the Fed's 2:45pm announcement are reflected in our market quotations for Feb. 20. See Scott (1965), Chap. 3, for more details.

25 The New York Times, Mar. 16, 1961.

26 The New York Times, Mar. 17, 1961.

27 The Wall Street Journal, Mar. 20, 1961. The market's interpretation of Treasury's announcement was at least partly correct: Treasury staff had decided that new Treasury issuance would continue to focus on short maturities (consistent with Operation Twist), but that refundings of oustanding Treasury debt would continue to take place at long maturities (The Wall Street Journal, Mar. 16, 1961). The thinking behind this policy was that holders of outstanding Treasury debt would roll their debt over, anyway, so that issuing longer-term securities to these investors would not affect the spread between long- and short-term yields and thus would not interfere with Operation Twist (ibid.). However, the market reaction to the Treasury announcement suggests that this policy in fact may have been misguided and counterproductive. Thus, after the Mar. 15 announcement, one could reasonably characterize the Treasury as being "partially committed" to Operation Twist rather than fully committed. 
announcements discussed above. Because the announcement was made after the market close, we use a one-day event window, from the market close on Mar. 15 to the market close on Mar. 16, to measure the effects of the announcement.

Our sixth and final announcement regarding Operation Twist occurred on April 6, 1961, and again corresponds to a weekly statistical release by the Federal Reserve. This release, covering the Fed's Treasury holdings for the week through Wednesday, April 5, showed a substantial increase in the Fed's holdings of longer-term Treasury securities, and in particular the first purchase by the Fed in many years of Treasury bonds with greater than ten years to maturity. These purchases provided renewed confirmation of the Fed's commitment to Operation Twist, and were reported as such by the press. ${ }^{28}$ The statistical release occurred "after the market had closed," so we use a one-day event window for this announcement, from the market close on Thursday, Apr. 6, to the market close on Friday, Apr. $7 .^{29}$

For each of these six announcements, we then collected data on Treasury market closing prices from the Government Securities column of The Wall Street Journal for the business days before, during, and after the announcement. ${ }^{30}$ (Although daily yield curve data are available in electronic format from the Federal Reserve Board and other sources, these data do not begin until 1962.) We focused on collecting data for a wide range of maturities that accurately characterize the yield curve at both the short and long ends; in particular, we collected data on Treasury securites with 3 months, 1 year, 2 years, 5 years, 10 years, and 30 years remaining to maturity. To reduce the influence of idiosyncratic changes in price for any single Treasury security on our results, we computed the average yield to maturity for the three Treasury securities closest to each target maturity listed above. ${ }^{31}$

28 The Wall Street Journal, Apr. 7, 1961, and Apr. 10, 1961.

29 The New York Times, Apr. 7, 1961.

30 As discussed above, these reported yields come from quotation sheets distributed by Treasury market dealers that were typically based on 2:30pm price quotations and thus do not correspond exactly to the 3:30pm closing prices in the market (Scott, 1965). However, they would typically be very close to the closing prices and we will refer to them as being closing prices for expositional convenience. Also, in a few cases (Mar. 15-16 and Apr. 7), data from The Wall Street Journal were unavailable or illegible, in which case we used Treasury yields for the same securities as reported by The New York Times.

${ }^{31}$ We exclude callable bonds from this analysis (which are quoted with a range of maturity dates spanning several years), in order to ensure that the maturity of the bond is accurately measured and that the price is free from any implicit option premia associated with callability. At the five-year maturity, there were only two noncallable securities with close to five years remaining to maturity, so we use two rather than three securities to measure yields at that maturity. 


\subsection{Hypothesis Tests}

The null hypothesis for our analysis is that changes in the expected net supply of long-term Treasury bonds - either through a change in issuance by the Treasury or a change in Federal Reserve purchases - have no effect on Treasury yields at any maturity. The alternative hypothesis is that a reduction in the net supply of long-term Treasuries - either through a decrease in Treasury issuance of long-term bonds or an increase in Federal Reserve purchases of long-term Treasury securities - should cause long-term Treasury yields to fall. ${ }^{32}$

Under the alternative hypothesis, the effect of Operation Twist on short-term Treasury yields is a little less clear. In the first two announcements in Table 2, President Kennedy and the Treasury gave no indication that the total quantity of Treasury issuance would be changed, only its composition. Thus, while the Treasury's issuance of long-term bonds would decrease, its issuance of short-term securities would increase. All else equal, this would tend to push short-term Treasury yields upward. However, whether this tendency is realized or not depends crucially upon the actions of the Federal Reserve: if the Fed does not change its target for the federal funds rate, then the shortest-term Treasury yields will remain essentially unchanged, since they are tightly tied to the federal funds rate. In other words, if the Fed maintains a constant target for the federal funds rate after the Treasury's change in issuance, then the Fed will end up neutralizing the Treasury's increased issuance of shorterterm Treasury securities by exchanging those securities on the open market for reserves, in order to maintain the funds rate peg. Thus, even under the alternative hypothesis, there may be no effect of Operation Twist on short-term Treasury yields if the Federal Reserve does not permit those yields to rise. However, we should not see short-term yields decrease as a result of Operation Twist, under either the null or alternative hypothesis.

To estimate the effects of Operation Twist, we would ideally like to have data on financial market expectations of the net supply of long-term bonds both before and after each announcement in Table 2, in order to measure the change in market expectations of supply attributable to each announcement. Unfortunately, no such data exist.

\footnotetext{
32 This sign prediction follows from a downward-sloping demand curve for long-term Treasuries: as the available quantity decreases, the equilibrium price should increase and the yield to maturity fall. Greenwood and Vayanos (2008) and Vayanos and Vila (2009) provide a formal model with preferred-habitat investors and risk-averse arbitrageurs that implies a downward-sloping demand curve for Treasury securities of each maturity.
} 
Nevertheless, we can test the null hypothesis by measuring the change in yields across each announcement and determining whether and to what extent the change is statistically significant - that is, how large is the change in yields relative to the unconditional standard deviation of Treasury yields - and whether the change is in the direction predicted by the alternative hypothesis. If the announcements consistently lead to significant effects in the direction predicted by the alternative, then we would reject the null and turn to the question of estimation of the total size of the effects of Operation Twist.

Finally, note that five of the six announcements identified in Table 2 represented a perceived increase in the commitment of the Treasury and Federal Reserve to Operation Twist. Each of these five announcements thus should have caused markets to revise downward their estimate of the current and future supply of long-term Treasury bonds, and should have led to a decrease in long-term Treasury yields under the alternative hypothesis. By contrast, the March 16 announcement was seen as a decrease in the commitment of the Treasury and Federal Reserve to the program, and thus should have caused markets to revise upward their estimate of the current and future supply of long-term Treasury bonds, leading to an increase in long-term Treasury yields.

\section{Results}

The results of the event study analysis described above are summarized in Table 3. The top panel reports Treasury yields at the market close the day before, the day of, and the day after each announcement. The second panel reports the change in Treasury yields across the event window for each announcement. The bottom panel reports the unconditional standard deviation of Treasury yield changes over one- and two-day windows as benchmarks for comparison. ${ }^{33}$

The statistical significance of each Treasury yield response in the table is assessed relative to the unconditional standard deviation for the same maturity and window size in the bottom panel. One, two, or three stars next to a number denotes statistical significance

\footnotetext{
${ }^{33}$ We discuss the 6- and 8-day changes below. Unconditional standard deviations are computed for 1962 , for two reasons: First, daily data on Treasury yields are available from the Federal Reserve Board beginning on January 2, 1962, but not before. Second, we want to compute an unconditional standard deviation that is not unduly influenced by Operation Twist itself, and 1962 largely postdates the Operation Twist period. The unconditional standard deviation of Treasury yield changes in 1963 and in 1964 are less than in 1962, so our measure of standard deviation here is conservatively large.
} 
Table 3: Treasury Yields around Operation Twist Announcements

Date 3-mo. $\quad 1$-yr. 2 -yr. $\quad 5$-yr. 10 -yr. 30 -yr.

Treasury Yields around Announcement Dates (percent):

$\begin{array}{lcccccc}\text { Feb. 1 (Wed.) } & 2.263 & 2.787 & 3.05 & 3.565 & 3.783 & 3.90 \\ \text { Feb. 2 (Thurs.) } & 2.273 & 2.78 & 3.007 & 3.53 & 3.747 & 3.86 \\ \text { Feb. 2 (Thurs.) } & 2.273 & 2.78 & 3.007 & 3.53 & 3.747 & 3.86 \\ \text { Feb. 3 (Fri.) } & 2.272 & 2.81 & 3.043 & 3.51 & 3.713 & 3.845 \\ \text { Feb. 8 (Wed.) } & 2.327 & 2.81 & 3.077 & 3.51 & 3.753 & 3.84 \\ \text { Feb. 9 (Thurs.) } & 2.327 & 2.827 & 3.077 & 3.51 & 3.753 & 3.835 \\ \text { Feb. 10 (Fri.) } & 2.355 & 2.85 & 3.097 & 3.52 & 3.743 & 3.83 \\ \text { Feb. 17 (Fri.) } & 2.387 & 2.827 & 3.037 & 3.49 & 3.73 & 3.795 \\ \text { Feb. 20 (Mon.) } & 2.422 & 2.833 & 3.023 & 3.47 & 3.713 & 3.795 \\ \text { Feb. 21 (Tues.) } & 2.497 & 2.887 & 3.01 & 3.40 & 3.65 & 3.735 \\ \text { Mar. 15 (Thurs.) } & 2.353 & 2.805 & 2.947 & 3.395 & 3.69 & 3.795 \\ \text { Mar. 16 (Fri.) } & 2.328 & 2.77 & 2.937 & 3.48 & 3.723 & 3.81 \\ \text { Apr. 6 (Thurs.) } & 2.283 & 2.858 & 2.993 & 3.445 & 3.733 & 3.82 \\ \text { Apr. 7 (Fri.) } & 2.282 & 2.808 & 2.98 & 3.435 & 3.73 & 3.805\end{array}$

Responses to Announcements (basis points):

1-day change, Feb. 1-2 $1-0.7$

1-day change, Feb. 2-3

2-day change, Feb. 8-10

$\begin{array}{cccccc}1 & -0.7 & -4.3^{*} & -3.5^{*} & -3.7^{* *} & -4^{* * *} \\ -0.2 & 3 & 3.7 & -2 & -3.3^{*} & -1.5 \\ 2.8 & 4 & 2 & 1 & -1 & -1 \\ 11^{* * *} & 6^{*} & -2.7 & -9^{* * *} & -8^{* * *} & -6^{* * *} \\ -2.5 & -3.5^{*} & -1 & 8.5^{* * *} & 3.3^{*} & 1.5 \\ -0.2 & -5^{* *} & -1.3 & -1 & -0.3 & -1.5\end{array}$

Cumulative Response (bp):

first four announcements

all six announcements

$\begin{array}{cccccc}14.7^{* * *} & 12.3^{* *} & -1.3 & -13.5^{* *} & -16^{* * *} & -12.5^{* * *} \\ 12^{*} & 3.8 & -3.7 & -6 & -13^{* * *} & -12.5^{* * *}\end{array}$

Unconditional Standard Deviation of Treasury Yield Changes (bp):

$\begin{array}{lllllll}\text { 1-day changes } & 2.14 & 1.99 & 2.25 & 1.93 & 1.73 & 1.15 \\ \text { 2-day changes } & 3.18 & 3.08 & 3.50 & 2.95 & 2.58 & 1.67 \\ \text { 6-day changes } & 4.87 & 5.77 & 6.45 & 5.56 & 4.00 & 2.90 \\ \text { 8-day changes } & 6.81 & 7.37 & 8.83 & 6.89 & 4.80 & 3.47\end{array}$

Notes: Treasury yields are averages for the three non-callable Treasury securities with remaining maturity closest to that listed. The choice of a 1- or 2-day event window is based on the timing of each announcement reported in Table $2 .^{*},{ }^{* *}$, and ${ }^{* * *}$ denote statistical significance at the $10 \%, 5 \%$, and $1 \%$ levels, respectively; significance for 1- and 2-day changes is relative to the unconditional standard deviations of 1- and 2-day changes in the bottom panel; significance for the cumulative changes is relative to the 6- and 8-day changes. The cumulative change for the first four announcements captures the initial effects of Operation Twist, since the fifth announcement was seen by markets as a policy reversal (see Table 2). Unconditional standard deviations are for 1962, due to data availability and to exclude the Operation Twist period. See text for details. 
for a two-sided $t$-test, even though the alternative hypothesis provides us with clear sign predictions for the shortest and longest maturities; we do this to minimize confusion (since the one-sided tests go in opposite directions for short and long maturities, and have no clear sign prediction at the intermediate 2-year maturity), and also to avoid the appearance of overstating the significance of the results in the table. However, we also discuss in the text statistical significance relative to a one-sided $t$-test when those results are interesting.

Of the six announcements in Table 3, the most remarkable is the Federal Reserve's endorsement of Operation Twist on February 20. Treasury yields with five or more years to maturity fell by 6 to 9 basis points (bp), with $t$-statistics in excess of 3 . But what makes these movements even more striking is the response of 3-month and 1-year Treasury yields, which simultaneously rose by 11 and 6bp, with the former statistically significant at the 1 percent level and the latter significant at the 5 percent level for a one-sided test in the direction of the alternative. The Wald statistic for the joint movement of all six Treasury yields during this two-day window is 53.5 , corresponding to a $p$-value of less than $10^{-9}$. Moreover, the yield curve response is completely consistent with the alternative hypothesis and thus raises serious questions about the validity of the null.

President Kennedy's introduction of Operation Twist on February 2 is almost as interesting. Longer-term yields fell by about $4 \mathrm{bp}$ that day, while short-term yields were about unchanged. The response of the 30-year yield is highly statistically significant, the 10-year yield response is significant at the 5 percent level, and the responses of the 2- and 5-year yields are significant at the 5 percent level for a one-sided test in the direction of the alternative. The Wald statistic for the joint change in yields is 16.6, with a $p$-value of 1.1 percent. Moreover, the yield curve response to this announcement is in the direction predicted by the alternative.

The response to the Treasury's announcement after the market close on Feburary 2 is not as strong as for the Fed's and President's announcements, above; nevertheless, the changes in the 10-, 30-, and 1-year Treasury yields are all statistically significant at the 10 percent level or better for one-sided tests in the directions predicted by the alternative (downward for the 10- and 30-year yields, and upward for the 1-year yield). The Wald statistic for the joint change in yields is 28.6, even larger than for Kennedy's announcement, because of the stronger upward "twist" at the 1- and 2-year maturities, a more unusual 
pattern. The $p$-value for this move is less than $10^{-4}$, and it is again in the direction predicted by the alternative.

The Treasury's surprise refunding announcement on March 15 is the one announcement in our sample that was perceived as a decrease in the government's commmitment to Operation Twist. Thus, the alternative hypothesis predicts that long-term interest rates should increase in response to that announcement. In fact, this is what we see in the data, particularly at the 5-year maturity, which is precisely the maturity at which the Treasury announced that the new supply would be forthcoming. Yields rose by 8.5bp at the 5-year maturity with a $t$-statistic of more than 4 , but the increases at the 10- and 30-year maturities are also statistically significant at the 5 and 10 percent levels, respectively, for a one-sided test in the direction of the alternative. At the same time, short-term yields twisted downward by 2.5 to $3.5 \mathrm{bp}$, with the 1-year yield response significant at the 5 percent level for a one-sided test. The Wald statistic for the joint movement of yields is 73.5, with a $p$-value of less than $10^{-13}$, and this movement is in the direction predicted by the alternative.

Finally, the Federal Reserve's statistical releases on February 9 and April 6 seem to have had little effect on the bond market. Although there is a statistically significant drop in the 1-year yield around the April 6 announcement, that response is not in the direction predicted by the alternative, so it would not be significant for a one-sided test. The Wald statistic for the Feb. 9 announcement is 5.0, with a $p$-value of 55 percent, while the Wald statistic for April 6 is 10.9, with a $p$-value of 9.2 percent.

Beyond the size and statistical significance of individual announcements, we investigate the size and significance of Operation Twist as a whole in two ways. First, we look at the cumulative effect of the first four announcements in our sample, each of which represented an increase in Treasury or Federal Reserve commitment to Operation Twist. Taken together, these first four announcements provide a reasonable estimate of the initial effects of Operation Twist on the yield curve: Not only is each of these announcements in the same direction, but they all occur within a period of three weeks during which essentially no other news regarding Operation Twist was released. As a result, we can have a high degree of confidence that these first four announcements capture essentially all of the information regarding Operation Twist that was released within the first three weeks of the program. One can interpret this cumulative effect as the initial effect of Operation Twist or what the total effect could have 
been with no future policy reversals or mixed signals.

The second way we investigate the overall effect of Operation Twist is by looking at the cumulative effect of all six of the announcements in our sample. Here, the interpretation is less clear-cut: For example, the fifth announcement, on March 15, reversed some of the initial effects of the program. There is also more time between the fourth, fifth, and sixth announcements and after the sixth announcement for more incremental information about Operation Twist to come to light, such as the weekly breakdown of Treasury holdings released by the Federal Reserve, the periodic issuance and refunding announcements by the Treasury, and the actual purchases and issuance of Treasury securities made by the Federal Reserve and Treasury. Nevertheless, summing up the effects of the six announcements in our sample gives an estimate of the total effects of Operation Twist, inclusive of the effects of policy reversals.

These cumulative changes are reported in the third panel of Table 3 . The statistical significance of the cumulative changes is assessed by comparing them to the unconditional standard deviations of yields over a correspondingly-sized 6- or 8-day window, reported in the bottom panel. As can be seen in the table, the cumulative change in yields after the first four announcements is highly statistically significant and in the direction predicted by the alternative. The Wald statistic for the joint yield curve response is 81.8 , with a $p$-value of less than $10^{-14}$. The cumulative effect, however, is moderate, amounting to no more than about $15 \mathrm{bp}$ even at the longest and shortest maturities.

The cumulative effect of all six announcements is somewhat smaller, and is only statistically significant at the longest and shortest maturities (10 years, 30 years, and 3 months), although the $t$-statistics for the long maturities remain close to 3 , and the 3-month response is significant at the 5 percent level in the direction of the alternative. The Wald statistic for the joint response is 35.2 , with a $p$-value of less than $10^{-5}$. Again, the total effect on the longest and shortest maturities appears to have been about 12 to $13 \mathrm{bp}$.

Thus, even though we have found that Operation Twist had a cumulative effect on the yield curve that is highly statistically significant, one could argue that, at 15 basis points, the effect is not very important economically. Indeed, Modigliani and Sutch argued:

Any effects, direct or indirect, of Operation Twist in narrowing the spread which further study might establish, are most unlikely to exceed some ten to twenty 
base points - a reduction that can be considered moderate at best.

(Modigliani and Sutch, 1966, p. 196)

However, it should be noted that a 15bp decline in the 10-year Treasury yield would be a typical response to a 100bp surprise cut in the federal funds rate target (Gürkaynak, Sack, and Swanson, 2005). Such a change in the federal funds rate would usually be regarded as a non-negligible easing of financial market conditions.

Whether a reduction of $15 \mathrm{bp}$ in long-term interest rates is economically significant or not may ultimately lie in the eye of the beholder. Nevertheless, it is reassuring that the effects in Table 3 are consistent with Modigliani and Sutch's findings. As discused above, the standard error of those authors' quarterly regression specification is over 9 basis points, too large for the effects in Table 3 to show up with any statistical significance in their analysis.

\section{Comparison to Other Studies}

While consistency of our results with Modigliani and Sutch's (1966, 1967) extensive analysis is reassuring, there have also been more recent studies of supply effects in the U.S. Treasury market. Here we relate the size of the effects estimated above to some of the more recent estimates of supply effects in the literature. For the purposes of comparability across studies, we normalize each estimate in terms of its predicted effect for QE2; that is, we report what effect each study would estimate a $\$ 600$ billion reduction in the supply of longer-term Treasury securities would have on longer-term Treasury yields. As discussed in Section 2, we regard Operation Twist and QE2 as being roughly similar in size, so that the predicted effect of the present paper for QE2 would be about 15bp.

Gagnon, Raskin, Remasche, and Sack (2010) study the Federal Reserve's purchases of longer-term Treasury and mortgage-backed securities between 2008 and mid-2009 — what one might call "QE1". They estimate the effects of QE1 using both high-frequency event study methods and a lower-frequency, monthly time series analysis. Gagnon et al. estimate that QE1 had an effect on the 10-year Treasury yield of about 91bp, using their event study methodology, or 52bp according to their monthly time series regressions. Since the $\$ 1.7$ trillion QE1 program was roughly three times the size of QE2, this would imply an effect of QE2 on the 10-year Treasury yield of about 14 to 30bp. Our estimates in this 
paper are consistent with the very bottom of this range. To the extent that this represents a discrepancy, it may be due to the fact that QE1 took place during a period of severe disruption and very low liquidity in financial markets (see, e.g., Gürkaynak and Wright, 2011), an environment in which those markets may have been more segmented and supply effects may have been correspondingly more potent.

D'Amico and King (2010) estimate the effects of Federal Reserve purchases of Treasury securities during QE1 using a panel data set containing the quantity, maturity, date of purchase, and CUSIP of each Treasury security purchased by the Fed through the program. They use differences in the cross-section of Treasury bond prices to estimate the effect of the Fed's Treasury purchases on Treasury yields. They estimate that, overall, the effect of the $\$ 300$ billion Treasury component of QE1 on the 10-year Treasury yield was about 50bp. Scaling this up to the size of QE2, this would imply an effect on the 10-year Treasury yield of about 100bp, far larger than the effect we estimate in the present paper. As with Gagnon et al. (2010), one reason for D'Amico and King's (2010) larger estimates may be that markets were unusually segmented during the period in which QE1 took place, making it easier for the Fed to move yields in any given market segment. Nevertheless, their estimates do not seem consistent with the Fed's experience during Operation Twist.

Hamilton and $\mathrm{Wu}$ (2011) relate Treasury supply effects to an affine term structure model using a preferred-habitat framework developed by Vayanos and Vila (2009). Hamilton and $\mathrm{Wu}$ estimate that $\$ 400$ billion of Treasury bond purchases by the Fed, focused on the longest maturities, would decrease long-term Treasury yields by about 17bp. Scaling this up to the size of QE2, this would imply an effect of about 26bp as a result of those programs. This is moderately higher than the effect estimated in the present paper, but this discrepancy may be accounted for by the fact that, in Operation Twist and QE2, the Fed purchased securities primarily at intermediate rather than the longest maturities, so that the effect on longer-term yields may be less than in Hamilton and Wu's idealized thought experiment. Recognizing this, Hamilton and Wu extend their analysis to the case where $\$ 400$ billion of Fed purchases take place at intermediate, $2^{1 / 2}$ - to 10 -year maturities, rather than the longest maturities; in this case, they estimate an effect on the 10-year Treasury yield of about $11 \mathrm{bp}$. Scaled up to the size of QE2 and Operation Twist, this would imply an effect of about 17bp, consistent with the present paper. 
Greenwood and Vayanos (2008) regress the monthly Treasury yield spread - the difference between long-term and short-term Treasury yields - on measures of the long-term (10 years or more to maturity) share of Treasury debt outstanding. They estimate that a $1 \%$ increase in the long-term share of Treasury debt increases the 20-year Treasury yield by 7.7bp. Scaling this up to the size of QE2, this would seem to imply an effect of those programs of about 39 to 54bp. However, most of the Federal Reserve's purchases of Treasury securities during Operation Twist and QE2 were concentrated at intermediate maturities of less than 10 years, and only a small fraction (about one-fourth) took place at the longest maturities of 10 years or more. As a result, Greenwood and Vayanos' estimates would imply an effect of those programs of roughly 10 to $16 \mathrm{bp}$, consistent with the present paper.

Krishnamurthy and Vissing-Jorgensen (2007) (KVJ) measure the effect of Treasury supply on the spread between Treasury yields and AAA-rated corporate bond yields. The idea is that AAA-rated corporate bonds are close substitutes for U.S. Treasuries and thus the Treasury-corporate spread can help to isolate the idiosyncratic effect of Treasury supply on Treasury yields. KVJ estimate that an increase in the total quantity of Treasuries outstanding equal to $1 \%$ of U.S. GDP raises Treasury yields overall by about 1.5 to $4 \mathrm{bp}$. While this estimate is of the same order of magnitude as in the present paper, the two estimates are nevertheless not directly comparable, because KVJ's analysis focuses on the total quantity of Treasury debt outstanding, while Operation Twist and QE2 involved no change in total Treasury debt, only a change in the relative supply of shorter vs. longer maturity Treasury securities.

Warnock and Warnock (2009) estimate a quantity effect on Treasury yields using monthly data on foreign official purchases of U.S. Treasury securities. The idea is that purchases of U.S. Treasury securities by the Bank of China or Bank of Japan are made primarily for exogenous reasons relating to the domestic economy or exchange rate interventions, and thus represent exogenous changes in the net supply of U.S. Treasuries to the private sector. Warnock and Warnock estimate that a decrease in the supply of Treasury securities of about $1 \%$ of U.S. GDP reduces the 10-year Treasury yield by about $19 \mathrm{bp}$. Scaling this up to the size of QE2 and Operation Twist would imply a reduction in longer-term Treasury yields of roughly 38 to $76 \mathrm{bp}$, substantially larger than the effect estimated by Krishnamurthy and Vissing-Jorgensen (2007). As with the KVJ analysis, though, Warnock and Warnock's es- 
timates are not directly comparable to those of the present paper, since Operation Twist and QE2 did not change the total quantity of Treasury debt outstanding, only the relative suppply of shorter vs. longer maturity Treasury securities.

Returning to the present paper, it is reassuring that several of the studies above, using completely different methods, arrive at estimates of the effects of QE2 that are in line with those of the present paper. A potential concern with the event-study methodology in general is that it restricts attention to only those news-worthy announcements that can be pinpointed to an exact date. If much of the news regarding Operation Twist was released incrementally, in between and after the six major announcements in Table 2, then it is possible that the cumulative effect of the six discrete announcements would miss much of the true cumulative effect of Operation Twist as a whole. The studies by Hamilton and Wu (2011) and Greenwood and Vayanos (2008) do not suffer from this criticism, and so their findings provide some evidence that our six major announcements may indeed have captured a large majority of the information and effects of the Operation Twist program.

\section{Conclusions}

For more than forty years, the conventional wisdom regarding Operation Twist has been driven by the results of low-frequency time series studies, particularly Modigliani and Sutch (1966, 1967). However, there are inherent problems with these lower-frequency methods, such as unobserved expectations variables, large standard errors, and particularly endogeneity, which would occur if the Federal Reserve increased its purchases of longer-term Treasury securities in response to upward pressure on longer-term interest rates.

The present paper has reexamined Operation Twist using a modern high-frequency event-study approach, which avoids the problems with lower-frequency methods discussed above. In contrast to Modigliani and Sutch, we find that Operation Twist had a highly statistically significant impact on longer-term Treasury yields. However, consistent with those authors, we find that the size of the effect was moderate, amounting to about 15 basis

points. This estimate is also consistent with the lower end of the range of estimates of Treasury supply effects in the literature.

Because Operation Twist and QE2 are similar in many important respects, it seems reasonable to expect the effects of QE2 on longer-term Treasury yields also to be about 15 
basis points. Although this may seem like a small effect in some respects, it nevertheless may be regarded as important by policymakers. In particular, 15bp is the typical response of the 10-year Treasury yield to a 100bp surprise cut in the federal funds rate (Gürkaynak, Sack, and Swanson, 2005), and such a shift in the stance of monetary policy would normally be viewed as substantial. In this respect, then, one could argue that the effects of Operation Twist (and QE2) were economically as well as statistically significant.

Finally, the benefits of these programs in terms of lower interest rates must be weighed against their costs to assess their overall desirability. Although we have not attempted to estimate the costs of Operation Twist or QE2 here, those costs are as important as the benefits for policy analysis, and thus future work on the nature and size of such costs would be welcome. 


\section{References}

Bernanke, Ben (2010). "The Economic Outlook and Monetary Policy," speech at the Federal Reserve Bank of Kansas City Economic Symposium, Jackson Hole, Wyoming, August 27, 2010.

Christiano, Lawrence, Martin Eichenbaum, and Charles Evans (1999). "Monetary Policy Shocks: What Have We Learned and to What End?" in Handbook of Macroeconomics 1A, John Taylor and Michael Woodford, eds. (Elsevier: Amsterdam), 65-148.

D'Amico, Stefania, And Thomas King (2010). "Flow and Stock Effects of Large-Scale Treasury Purchases," Federal Reserve Finance and Economics Discussion Series 2010-52.

E21 Team (2010). "An Open Letter to Ben Bernanke," The Wall Street Journal, Nov. 16, 2010, fullpage advertisement, A17. Available at http://www.economics21.org/commentary/e21s-openletter-ben-bernanke

Faust, Jon, Eric Swanson, and Jonathan Wright (2004). "Identifying VARs based on HighFrequency Futures Data," Journal of Monetary Economics 51, 1107-31.

Fleming, Michael and Eli Remolona (1999). "Price Formation and Liquidity in the U.S. Treasury Market: The Response to Public Information," Journal of Finance 54, 1901-15.

Gagnon, Joseph, Matthew Raskin, Julie Remasche, and Brian Sack (2010). "Large-Scale Asset Purchases by the Federal Reserve: Did They Work?" Federal Reserve Bank of New York Staff Report 441.

Greenwood, Robin and Dimitri Vayanos (2008). "Bond Supply and Excess Bond Returns," NBER Working Paper 13806.

Gürkaynak, Refet, Brian Sack, And Eric Swanson (2005). "Do Actions Speak Louder Than Words? The Response of Asset Prices to Monetary Policy Actions and Statements," International Journal of Central Banking 1, 55-93.

Gürkaynak, Refet And Jonathan Wright (2011). "Macroeconomics and the Term Structure," Journal of Economic Literature, forthcoming.

Hamilton, James and Jing (Cynthia) Wu (2011). "The Effectiveness of Alternative Monetary Policy Tools in a Zero Lower Bound Environment," unpublished manuscript, University of California, San Diego.

Jones, Charles, Owen Lamont, and Robin Lumsdaine (1998). "Macroeconomic News and Bond Market Volatility," Journal of Financial Economics 47, 315-37.

Krishnamurthy, Arvind and Annette Vissing-Jorgensen (2007). "The Demand for Treasury Debt," NBER Working Paper 12881.

Meulendyke, Anne-Marie (1998). U.S. Monetary Policy and Financial Markets (Federal Reserve Bank of New York).

Modigliani, Franco and Richard Sutch (1966). "Innovations in Interest Rate Policy," American Economic Review 56, 178-97.

Modigliani, Franco and Richard Sutch (1967). "Debt Manaqement and the Term Structure of Interest Rates: An Empirical Analysis of Recent Experience," Journal of Political Economy 75, 569-89.

New York Times, The. Mar. 16, 1961. "Bonds: Treasury Bills Firm as Other Gilt-Edge Issues Show Declines," p. 56. 
New York Times, The. Mar. 17, 1961. "Bonds: Prices for Most Issues Decline in Light Trading," p. 48.

New York Times, The. Apr. 7, 1961. "Bonds: U.S. Issues Score Their First Good Gain in a Month," p. 46.

Scott, Ira (JR.) (1965). Government Securities Market (New York: McGraw-Hill).

Vayanos, Dimitri and Jean-Luc Vila (2009). "A Preferred-Habitat Model of the Term Structure of Interest Rates," unpublished manuscript, London School of Economics.

Wall Street Journal, The. Feb. 3, 1961. "White House Sees Backing by FRB on Rate Policy," p. 2.

Wall Street Journal, The. Feb. 3, 1961. "Treasurys, Prime Corporates Advance As Trading Picks Up," p. 18.

Wall Street Journal, The. Feb. 6, 1961. "The Bond Markets: Top-Grade Corporates, Treasurys Up in Week As Trading Increased," p. 16.

Wall Street Journal, The. Feb. 9, 1961. "Kennedy Says FRB to Control Long-Term Rates," p. 3.

Wall Street Journal, The. Feb. 10, 1961. "Reserve Board Raises Long-Term Treasury Holdings," p. 6 .

Wall Street Journal, The. Feb. 21, 1961. "Reserve is Buying Long Treasurys in Open Market in Policy Reveral," p. 3.

Wall Street Journal, The. Feb. 21, 1961. "Long Treasurys Show Gains, Top Corporates Up a Bit," p. 21.

Wall Street Journal, The. Feb. 23, 1961. "The Bond Markets: Longer Treasurys Rise Almost a Point; Prime Corporates Also Gain," p. 23.

Wall Street Journal, The. Feb. 24, 1961. "FRB Last Week Bought Treasurys in 5-10 Year Range," p. 6.

Wall Street Journal, The. Mar. 16, 1961. "Treasury to Offer New 35/8\%, 33/8\% Bonds for Swap," p. 4.

Wall Street Journal, The. Mar. 20, 1961. "Bond Markets: Treasurys Led Week's Drop; Top Corporates Fell as Much as 1/2-Point," p. 20.

Wall Street Journal, The. Apr. 7, 1961. "Reserve System Steps Up Buying of Federal Issues," p. 4.

Wall Street Journal, The. Apr. 10, 1961. "The Bond Markets: High-Grade Corporates Eased; Treasurys Were Mixed in Slow Week," p. 17.

Warnock, Frank and Veronica Warnock (2009). "International Capital Flows and U.S. Interest Rates," Journal of International Money and Finance 28, 903-19.

Woolley, John And Gerhard Peters (2010). The American Presidency Project (online: Santa Barbara, CA). Available at http://www.presidency.ucsb.edu/ws/?pid=8111. 